\title{
FILM DOKUMENTER TARI REJANG SUTRI "TARIAN PENOLAK BALA" TRADISI KHAS DESA BATUAN
}

\author{
Ni Made Sthiti Nur Hita ${ }^{1}$, Gede Saindra Santyadiputra ${ }^{2}$, Gede Aditra Pradnyana ${ }^{3}$ \\ $1,2,3$ Jurusan Pendidikan Teknik Informatika, Universitas Pendidikan Ganesha \\ Singaraja, Indonesia \\ E-mail : dektha05@gmail.com ${ }^{1}$, gsaindras@undiksha.ac.id ${ }^{2}$,gede.aditra@undiksha.ac.id ${ }^{3}$
}

\begin{abstract}
Abstrak
Tari Rejang Sutri merupakan salah satu warisan budaya yang terdapat di Desa Batuan, Kecamatan Sukawati, Kabupaten Gianyar. Tari Rejang Sutri merupakan tarian sakral yang ditarikan mulai sasih kalima sampai sasih kasanga. Penelitian ini bertujuan untuk (1) mengimplementasikan hasil rancangan Film Dokumenter Tari Rejang Sutri "Tarian Penolak Bala" Tradisi Khas Desa Batuan, (2) untuk mengetahui respon masyarakat terhadap hasil akhir Film Dokumenter Tari Rejang Sutri "Tarian Penolak Bala" Tradisi Khas Desa Batuan. Jenis penelitian yang digunakan adalah penelitian dan pengembangan dengan model cyclic strategy. Teknik pengumpulan data dilakukan dengan cara observasi, wawancara, studi pustaka, penyebaran angket, dan dokumentasi. Penelitian ini diimplementasikan menggunakan Adobe Premiere Pro CC 2015 sebagai aplikasi pengedit video dan Adobe Audition Pro CC 2015 untuk aplikasi pengedit audio. Hasil penelitian menunjukkan bahwa Film Dokumenter Tari Rejang Sutri "Tarian Penolak Bala" Tradisi Khas Desa Batuan dalam kriteria sangat baik berdasarkan persentase yang diperoleh dari hasil uji efektivitas sebesar $93.5 \%$ yang masuk dalam kategori sangat baik berdasarkan persentase yang telah diperoleh, serta berdasarkan analisis terhadap 30 orang responden yang berasal dari kalangan masyarakat umum, dinyatakan bahwa film dokumenter ini mendapatkan total persentase sebesar $92.37 \%$ yang masuk dalam kategori sangat baik berdasarkan persentase yang telah diperoleh. Hal itu menunjukkan bahwa film dokumenter ini sudah mencapai hasil yang maksimal.
\end{abstract}

Kata kunci : Sutri, Film Dokumenter, Cyclic Strategy.

\begin{abstract}
Rejang Sutri Dance is one of the cultural heritages found in the Batuan Village, Sukawati District, Gianyar regency. Rejang Sutri Dance is a sacred dance that danced from sasih kalima to sasih kasanga. This study aims to (1) implement the results of the Documentary Film Rejang Sutri Dance "Dance of Resistant Bala" typical tradition of Village Batuan. (2) to know the public response to the final result of Documentary Rejang Sutri Dance "Dance of Resistant Bala" typical tradition of Batuan Village. The type of research used is research and development with cyclic strategy model. Technique of collecting data is done by observation, interview, literature study, questionnaire, and documentation. This research is implemented using Adobe Premiere Pro CC 2015 as a video editing application and Adobe Audition Pro CC 2015 for audio editing application. The results showed that the Documentary Film Rejang Sutri Dance "Dance of Resistant Bala" typical tradition of Batuan Village in the criteria is very good based on the percentage obtained from the effectiveness percentage of $93.5 \%$ which is included in the category very well based on the percentage that has been obtained, and based on the analysis of 30 respondents who come from the general public, stated that this documentary film gets a total percentage of $92.37 \%$ either based on the percentages that have been obtained. It shows that this documentary film has achieved maximum results.
\end{abstract}

Keywords: Sutri, Documentary Film, Cyclic Strategy.

\section{PENDAHULUAN}

Bali merupakan salah satu pulau kecil di Indonesia yang memiliki beraneka ragam seni dan budaya. Keberagaman seni dan budaya di Bali dijiwai oleh prinsip desa mawa cara (setiap wilayah memiliki kebiasaan berbeda), ini dapat dilihat dari wujud fisik, kandungan estetisnya, dan juga konteks penyajiannya. Seni merupakan salah satu unsur terpenting dari tradisi budaya Bali. Terdapat berbagai macam kesenian yang tersebar di seluruh wilayah di Bali, salah satunya yaitu seni tari. Kesenian di Bali khususnya seni tari memiliki keterkaitan dengan upacara agama yang dilaksanakan. Di balik keberagaman itu, terdapat untaian kompleksitas nilai budaya, baik dari tradisi lama maupun budaya baru yang tercipta [1]. 
Di daerah Gianyar terdapat tarian sakral yaitu tari rejang yang sangat beragam, salah satunya adalah Rejang Sutri yang ada di Desa Batuan, Kecamatan Sukawati, Kabupaten Gianyar. Tari rejang sutri ini berbeda dengan tari rejang yang biasa kita temui, mulai dari fungsi, tata rias dan busananya sampai hari pementasannya yang sangat unik. berdasarkan hasil wawancara dengan Bendesa Adat Batuan yaitu Bapak Made Jabur, didapatkan informasi bahwa tari rejang sutri di Desa Batuan berfungsi sebagai tari tolak bala yang ditarikan untuk melindungi masyarakat setempat dari kemarahan Ratu Gede Mecaling. Ratu Gede Mecaling dendam kepada masyarakat batuan karena telah mengusirnya dan berjanji akan mengganggu masyarakat Batuan dengan menyebarkan penyakit.

Untuk mengetahui wawasan masyarakat tentang tari sakral rejang sutri yang ada di Desa Batuan, maka dilakukan observasi dengan menyebarkan angket kepada 30 orang responden yang diambil secara acak dari 2 daerah populasi yaitu 20 sampel dari masyarakat di Desa Batuan dan masyarakat umum yang diambil 10 sampel. Hasil observasi menyatakan bahwa $73 \% \quad$ (22 orang) menyatakan mengetahui tari rejang sutri dan $27 \%$ (8 orang) tidak mengetahui tarian ini, dimana sebagian besar masyarakat di luar Desa Batuan tidak mengetahui tentang tarian ini. Dalam observasi tersebut juga ditemukan bahwa $30 \%$ (9 orang) yang mengetahui fungsi dari rejang sutri ini dan $70 \%$ (21 orang) tidak mengetahui fungsi tarian ini. Hal yang lebih memprihatinkan yaitu sebanyak $100 \%$ (30 orang) tidak mengetahui asal mulanya tari rejang sutri. Hal ini sangat memprihatinkan, mengingat banyak hal yang bisa di dapat selama menjalani tradisi ini seperti nilai pendidikan, nilai historis dan keyakinan, nilai sosial dan komunikasi, dan nilai kebersamaan.

Melihat hal tersebut, maka dibutuhkan sebuah media sosialisasi berupa dokumentasi untuk dapat mendokumentasikan, mempublikasikan, dan menyampaikan pentingnya tarian ini kepada masyarakat. Salah satu cara yang dapat dilakukan yaitu dengan pembuatan Film Dokumenter. Film merupakan media komunikasi sosial yang terbentuk dari penggabungan dua indra yaitu penglihatan dan pendengaran. Sebuah film dokumenter diharapkan dapat merepresentasikan bentuk, suara serta fakta-fakta yang ada. Film dokumenter menyajikan realita melalui berbagai cara dan dibuat untuk berbagai tujuan [2]. Film dokumenter mengandung unsur cerita yang dapat menyampaikan sebuah gagasan atau pesan yang subjektif dari pembuat kepada audiensnya, dengan harapan menarik perhatian para audiens untuk peduli terhadap permasalahan yang ada [3].

Penelitian mengenai perancangan film dokumenter sudah pernah dilakukan sebelumnya oleh peneliti lain. Salah satunya yaitu penelitian yang berjudul "Perancangan Film Dokumenter Seni Pertunjukan Topeng Malang" oleh Evan Lawrence yang menghasilkan sebuah penelitian film dokumenter yang menampilkan video, tata suara, dan teks. Film yang berdurasi 17 menit ini memberikan informasi tentang kesenian tradisional Topeng Malang. Tidak jauh berbeda dengan penelitian yang berjudul "Perancangan Film Dokumenter Selonding Nyanyianmu Semangat Kami Sebagai Kebudayaan Khas Desa Tenganan Pegringsingan Bali" oleh I Gusti Made Dio Damalla Pratama dan Bambang Mardiono Soewito (2015) yang menghasilkan sebuah film dokumenter yang mempunyai tampilan cerita yang menarik tentang keindahan kebudayaan khas Desa Tenganan Bali. Film yang berdurasi 30 menit ini telah memenuhi segala kebutuhan target audiens mengenai selonding dan mampu menarik minat mereka untuk peduli terhadap kebudayaan Bali berdasarkan hasil post test yang dilakukan di beberapa sekolah [3].

Berdasarkan uraian tersebut, agar tari rejang sutri ini nantinya tidak punah dan tidak dilupakan, peneliti menawarkan solusi dengan pembuatan Film Dokumenter Tari Rejang Sutri "Tarian Penolak Bala" Tradisi Khas Desa Batuan. Dikembangkannya film ini bertujuan agar tari rejang sutri nantinya terdokumentasi dan dapat lebih dikenal oleh masyarakat luas, khususnya fungsi dari tari rejang sutri di Batuan. Selain itu juga dapat membantu dalam melestarikan keberadaan tari rejang sutri sebagai tarian sakral di Bali.

\section{KAJIAN TEORI}

A. Tari Sakral Rejang Sutri Batuan

Rejang adalah tari upacara yang memiliki gerak-gerak tari yang sederhana, lemah gemulai, dan bernuansa meditatif. Di Desa Batuan terdapat tari rejang yang ditarikan saat sasih kalima sampai sasih kasanga yang disebut dengan Rejang Sutri.

Menurut Bapak I Made Djimat, tarian ini berawal dari peperangan Ratu Gede Mecaling dengan I Dewa Babi. Dalam mengadu kesaktian mereka, yang menjadi sarana adalah babi guling. Babi guling milik I Gede Mecaling kakinya diikat dengan tali benang dan satunya lagi milik Dewa Babi diikat dengan tali kupas. Guling siapa yang ikatannya putus maka 
dianggap kalah. Dalam perang guling tersebut, Ratu Gede Mecaling kalah dan akhirnya diusir dari Batuan.

Ratu Gede Mecaling tidak menerima kekalahannya dan ia berjanji sewaktu-waktu akan datang lagi untuk mengganggu daerah tersebut dengan menebar wabah penyakit kepada masyarakat. Ketakutan inilah yang menjadi awal munculnya tari Rejang Sutri di Desa Batuan. Rangkaian yang tidak terpisahkan dari pementasan ini adalah sebuah gocekan (sabung ayam) yang juga dilaksanakan setiap hari sebelum pementasan tari rejang sutri.

Tari rejang sutri memiliki fungsi sebagai tari wali dan tari tolak bala yang wajib dipertunjukkan menjelang sasih kalima sampai sasih kasanga yang pertunjukannya setiap hari mulai pukul 19.00 Wita sampai selesai. Masyarakat Desa Batuan berharap dengan dipertunjukkannya tari ini keharmonisan dan keselamatan dunia tetap terjaga.

\section{B. Film Dokumenter}

Film dokumenter adalah film yang mendokumentasikan kenyataan. Kunci utama dari film dokumenter adalah penyajian fakta. Tidak seperti film fiksi, film dokumenter tidak memiliki plot (rangkaian peristiwa dalam film yang disajikan pada penonton secara visual dan audio), namun memiliki struktur yang umumnya didasarkan oleh tema atau argument [4]. Film dokumenter ini berhubungan langsung dengan orang, tokoh, peristiwa, dan lokasi yang nyata. Struktur bertutur film dokumenter umumnya sederhana dengan tujuan memudahkan penonton untuk memahami [5].

Sejalan dengan perkembangan zaman, film dokumenter memiliki bentuk dan gaya bertutur yang bervariasi. (Ayawaila, 2008) dalam bukunya menyebutkan bahwa terdapat 12 jenis film dokumenter yang berdasarkan bentuk dan gaya bertutur yaitu, (1) laporan perjalanan, (2) sejarah, (3) biografi atau potret, (4) perbandingan, (5) kontradiksi, (6) ilmu pengetahuan, (7) nostalgia, (8) rekonstruksi, (9) investigasi, (10) association picture story, (11) buku harian, (12) docudrama [6].

\section{Teknik Pengambilan Gambar}

Pengambilan gambar adalah tahapan terpenting di dalam proses produksi. Jika sudah mengetahui mutu gambar yang baik, maka akan didapatkan gambar yang lebih "hidup" dan bisa mengarahkan perhatian penonton kepada objek tertentu di dalam gambar [7]. Dalam pengambilan gambar, kameramen memiliki standard shot atau komposisi gambar. Adapun jenis-jenis shot diantaranya : Close Up, Medium Close Up, Big Close Up, Extreme Close Up,
Medium Shot, Long Shot, Over Shoulder Shot,dan Knee Shot $[8,9]$.

Selain ukuran gambar, hal penting lainnya yang harus dikuasai oleh seorang kameramen yaitu sudut pengambilan gambar. Sudut pengambilan gambar atau camera angle yaitu penempatan atau posisi kamera terhadap suatu sudut tertentu. Terdapat beberapa angle yaitu, Low Angle, Straight Angle, High Angle, Bird Eye View, Frog Eye, dll [8].

Pergerakan kamera juga dapat mempengaruhi hasil pengambilan gambar. Adanya gerakan kamera akan memberikan dimensi yang lain dari suatu gambar. Ada beberapa macam gerakan kamera, diantaranya Panning, Tilting, Tracking, Zooming, Arching, Pedestal atau Crane, Crabbing, dan Following [3].

\section{Tahapan Pembuatan Film}

Pembuatan Film Dokumenter Tari Rejang Sutri dibagi menjadi tiga tahapan yaitu, tahapan praproduksi, tahapan produksi, dan tahapan pasca produksi [6]. Tahapan pra produksi dilakukan tahap penemuan ide, perencanaan, dan persiapan [10]. Tahapan produksi dilakukan pengambilan gambar dan tahapan pasca produksi dilakukan editing.

\section{E. Tahap Editing}

Editing berguna untuk memperpanjang atau memendekkan waktu, mengontrol waktu, memberikan penekanan terhadap shot tertentu, dan membentuk alur cerita. Editing merupakan salah satu proses yang sangat menentukan. Editing dilakukan pada tahap pasca produksi yaitu setelah semua tahap produksi selesai dilakukan. Ada empat teknik editing yaitu, (1) live on tape, (2) retakes, (3) rekaman bagian demi bagian, (4) single source recording [8].

Selain teknik editing, juga terdapat empat jenis editing yaitu, (1) hot editing, (2) switching, (3) editing in camera, (4) editing pasca produksi. Dalam tahapan editing pemilihan transisi juga sangat menentukan hasil akhir dari film yang dibuat. Transisi adalah metode yang digunakan untuk menghubungkan dari satu gambar ke gambar lainnya. Terdapat tiga jenis transisi yaitu, (1) cut, (2) mix, (3) fade.

\section{F. Model Cyclic Strategy}

Model cyclic strategy atau strategi berputar merupakan sebuah metode yang ada kalanya suatu tahap perlu diulang kembali sebelum tahap berikutnya dilanjutkan. Pengulangan tahap ini sering disebut dengan loop. Tahaptahap dalam model cyclic strategy diantaranya, (1) brief, (2) tahap 1, (3) tahap 2, (4) evaluasi 1, 
(5) tahap 3, (6) evaluasi 2, (7) tahap 4, (8) outcome [11].

\section{METODOLOGI}

\section{A. Metode penelitian}

Metode penelitian yang digunakan dalam Film Dokumenter Tari Rejang Sutri "Tarian Penolak Bala" Tradisi Khas Desa Batuan adalah metode pengembangan dengan model cyclic strategy. Berikut ini merupakan tahapan yang terdapat pada model cyclic strategy:

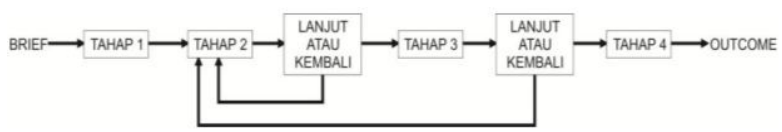

Gambar 1. Cyclic Strategy (Sarwono \& Lubis, 2007).

Model cyclic strategy merupakan sebuah model yang ada kalanya suatu tahap perlu diulang kembali sebelum dilanjutkan ke tahap selanjutnya. Pengulangan tersebut sering disebut looping. Pada model cyclic strategy terdapat dua kali evaluasi yang dapat meminimalisir kesalahan yang diperbuatan saat melakukan penelitian ini. Setiap tahapan yang ada pada model cyclic strategy memiliki keterkaitan satu sama lain sehingga semua tahap harus terlewati secara terstruktur. Rincian tahapan dalam model cyclic strategy yaitu:

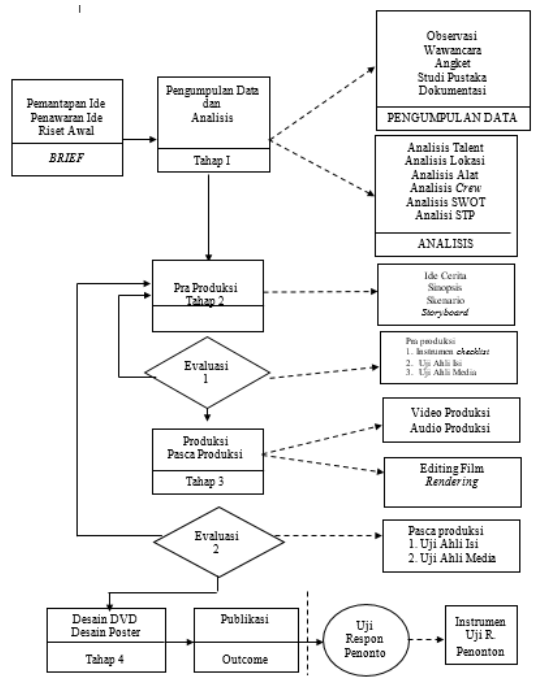

Gambar 2. Tahap-Tahap Cyclic Strategy

1) Brief (Pemantapan Ide, Penawaran Ide, Riset Awal)

Brief merupakan tahap awal dari perancangan film dokumenter Tari Rejang Sutri. Pada tahapan ini terdapat tiga fase yaitu, pemantapan ide, penawaran ide, dan riset awal.
2) Tahap 1 (Pengumpulan Data dan Analisis Cerita)

Pada tahap 1 dalam metode cyclic strategy dibagi menjadi 2 fase, yaitu

1. Pengumpulan Data

Teknik pengumpulan data dilakukan dengan lima cara, yaitu observasi, wawancara, studi pustaka, penyebaran angket, dan dokumentasi.

2. Analisis Cerita

Hasil dari fase pengumpulan data kemudian dianalisis guna mengetahui kelebihan, kekurangan maupun target audiens film dokumenter. Ada tiga tahap analisis yang dilakukan, yaitu :

a) Analisis Kebutuhan Film

Analisis kebutuhan film merupakan pemaparan kebutuhan apa saja yang perlu dipersiapkan dan disediakan terkait kebutuhan yang akan digunakan dalam film. Dalam analisis kebutuhan film dilakukan analisis talent, analisis lokasi, analisis alat, dan analisis crew.

b) Analisis SWOT (Strenght, Weakness, Opportunity, Threat)

Analisis SWOT dilakukan untuk mengetahui kekuatan, kelemahan, kesempatan yang bisa didapat, serta ancaman yang mungkin terjadi pada film tersebut.

c) Analisis STP (Segmentation, Targeting, Positioning)

Setelah melewati analisis SWOT, dilakukan penetapan target audiens sebagai ketentuan penyebaran film ke masyarakat luas. Analisa STP yang terdiri dari beberapa kriteria berupa pemilahan (segmentating), tujuan/target(targeting), penempatan (positioning).

3) Tahap 2 (Pra Produksi)

Pada tahap 2 berisi metode perancangan film bagian pra produksi. Pra produksi merupakan tahapan persiapan atau perencanaan dalam pembuatan sebuah film. Pra produksi meliputi beberapa tahapan, yaitu perancangan ide cerita, sinopsis, skenario, dan storyboard.

4) Evaluasi 1 (Mengecek Keterlaksanaan Tahap 1 dan Tahap 2)

Setelah tahap 2 dilaksanakan, akan ada pengujian yang bertujuan mengecek kembali apakah semua bagian dalam tahap 1 dan tahap 2 telah benar-benar terlaksana. Jika ada yang belum terlaksana maka akan dilakukan looping / 
pengulangan dengan merevisi kembali rancangan film.

5) Tahap 3 (Produksi dan Pasca Produksi)

Pada tahap ini terdiri dari fase produksi dan pasca produksi.

1. Produksi

Pada tahap ini desain film yang berupa ide cerita, sinopsis, skenario, dan storyboard yang sudah dibuat pada tahap pra produksi akan dikembangkan. Pada tahap produksi dilakukan shooting dan audio recording

2. Pasca Produksi

Hasil dari fase produksi yang berupa suara dan gambar akan diproses kembali pada fase pasca produksi agar film lebih terstruktur dan menarik. Dalam tahapan pasca produksi dilakukan beberapa hal yaitu, editing, mixing, dan rendering.

6) Evaluasi 2 (Mengecek Keterlaksanaan

Tahap 3)

Setelah tahap 3 ini akan ada pengujian yang bertujuan untuk mengecek kembali apakah pada tahap 3 telah terlaksana. Sebelum di publikasikan, sebuah film harus melalui tahap evaluasi guna mengetahui kelayakan film yang telah di buat.

7) Tahap 4 (Burning dan Desain)

Pada tahap ini dilakukan proses burning dan pengkemasan film ke dalam bentuk DVD sesuai dengan format yang telah di tentukan.

\section{8) Outcome}

Outcome merupakan tahapan terakhir dari pembuatan film dokumenter ini. Tahap terakhir yaitu publikasi.

\section{B. Metode Pengolahan Data}

1) Uji Validitas

Validitas adalah suatu tingkatan yang mengukur karakteristik yang ada dalam penyelidikan. Uji validitas ini dilakukan saat tahap evaluasi 1 yaitu pengujian terhadap tahap pra produksi dan tahap evaluasi 2 yaitu pengujian terhadap hasil pasca produksi. Uji validitas dilakukan menggunakan uji gregori dengan rumus :

$$
V i=\frac{D}{(A+B+C+D)}
$$

2) Pengujian Film

Pengujian film dilakukan untuk menguji hasil film yang telah selesai dibuat. Rumus yang digunakan untuk mencari persentase hasil pengujian yaitu :

$$
\text { Persentase }=\frac{\text { Skor Perolehan }}{\text { Skor Maksimal }} X 100 \%
$$

\section{HASIL DAN PEMBAHASAN}

\section{A. Hasil Penelitian}

Film dokumenter tari rejang sutri Desa Batuan ini mampu memberikan informasi mengenai tari rejang sutri yang ada di Desa Batuan baik dari segi sejarah, pelaksanaan tari rejang sutri, dan nilai-nilai yang terkandung dalam tari rejang sutri ini sekaligus dapat digunakan sebagai media untuk melestarikan tari rejang sutri itu sendiri. Hasil penelitian ini dijabarkan sebagai berikut :

a) Hasil Tahap Brief (Pemantapan Ide, Penawaran Ide, Riset Awal)

Pada tahapan ini dihasilkan beberapa pengetahuan awal dari topik yang dibahas yang nantinya dapat digunakan sebagai pedoman dalam pembuatan film dokumenter ini. Selain itu pada tahap brief dilaksanakan pengajuan topik ke pihak Jurusan Pendidikan Teknik Informatika dan riset awal mengenai topik yang diajukan. Topik tersebut telah diajukan dan disetujui pada tanggal 20 Juli 2016.

b) Hasil Tahap 1 (Pengumpulan Data dan Analisis Cerita) berikut :

Hasil dari tahap 1 dapat dijabarkan sebagai

a) Pengumpulan Data

Tahap pengumpulan data dilakukan untuk mendapatkan informasi awal mengenai topik yang akan dibahas.

1) Observasi

Hasil observasi didapatkan lima orang narasumber yang nantinya akan membantu peneliti dalam mencari informasi. Selain itu teknik observasi juga dilakukan untuk menentukan lokasi-lokasi shooting yang sesuai dengan cerita pada film.

2) Wawancara

Tahap wawancara dilaksanakan dengan beberapa narasumber yang terkait untuk mengetahui informasi tentang Tari Rejang Sutri. Adapun narasumber yang diwawancarai untuk menunjang penelitian ini adalah Made Jabur (Bendesa Batuan), I Made Djimat (Seniman tari), Wayan Martha (Tokoh Masyarakat Batuan), Wayan Suda (Jero Mangku Desa Batuan), dan I Wayan Budiarsa, S.Sn., M.Si (Akademisi Seni) 
3) Studi Pustaka

Peneliti menggunakan lima jurnal, delapan buku, dan empat film dokumenternyang dapat dijadikan acuan dan pedoman selama pembuatan film dokumenter tari rejang sutri.

4) Penyebaran Angket

Penyebaran angket menggunakan 20 orang responden yang berasal dari Desa Batuan dan 10 orang responden yang berasal dari luar Desa Batuan namun masih dalam lingkungan Kabupaten Gianyar.

5) Dokumentasi

Dokumentasi dilakukan secara terjadwal untuk wawancara dengan narasumber sedangkan dokumentasi selain itu dilakukan secara acak.

b) Analisis Cerita

Hasil analisis film adalah sebagai berikut :

1) Analisis Kebutuhan Film Ada beberapa hal yang dilakukan dalam analisis kebutuhan film, yaitu :

- Analisis Talent

Hasil analisis ini didapatkan lima orang narasumber yang nantinya akan membantu memberi informasi untuk penelitian ini.

- Analisis Lokasi

Lokasi shooting akan berpusat di Desa Batuan, Sukawati - Gianyar karena film ini akan lebih berfokus pada mengangkat tari rejang sutri yang ada di Desa Batuan.

- Analisis Alat

Adapun peralatan yang digunakan dalam pembuatan film dokumenter ini adalah Kamera DSLR Canon 7D, Kamera DSLR Canon 60D, Kamera DSLR Canon 700D, Kamera Mirolless Sony A6000, Drone, Tripod, Microphone (external), LED Video Lighting, Clip On Microphone, Komputer

- Analisis Crew

Crew film dibutuhkan dalam membantu proses produksi saat shooting. Adapun crew film dalam pembuatan film ini yaitu :

- Produksi : PTI Undiksha

- P. Skenario : Ni Made Sthiti Nur Hita

- Sutradara : Ni Made Sthiti Nur Hita
- Kamera 1: Ni Made Sthiti Nur Hita

- Kamera 2 : I Putu Andy Gunawan

- Kamera 3 : Ni Kadek Oka Aryanti

- Editor : Ni Made Sthiti Nur Hita

- Narator : Diah Utami Chandra Sari

- Analisis SWOT

Hasil analisis SWOT yaitu :

- Strength (Kekuatan)

Kekuatan film ini terletak pada ide cerita yang diangkat yang merupakan sebuah tradisi bersejarah dan juga berkaitan dengan legenda setempat. Selain itu film ini juga menampilkan ilustrasi sehingga informasi yang disampaikan dalam film ini menjadi lebih jelas dan menarik.

- Weakness (Kelemahan)

Kelemahan film ini terletak pada keterbatasan informasi mengenai keberadaan tari rejang sutra, keterbatasan biaya produksi film, keterbatasan alat, dan keterbatasan crew film.

- Opportunity (Kesempatan)

Film ini dapat dijadikan media dokumentasi dan dapat digunakan untuk mempromosikan serta menyebarluaskan tradisi tari rejang sutri.

- Threat (Ancaman) Dalam menentukan jadwal pengambilan gambar untuk momen pertunjukkan tari rejang sutri sulit untuk dilakukan dikarenakan terbatas oleh waktu.

- Analisis STP

Hasil analisis STP yaitu :

- Segmentation (Pemilihan)

Film ini ditujukan untuk semua wilayah yang ada di Indonesia. Film ini dapat ditonton oleh khalayak umum dari segala lapisan sosial.

- Targeting (Target)

Target utama penyebaran film adalah badan/organisasi/komunitas yang bergerak di bidang kesenian khususnya kesenian Bali yang bertujuan untuk melestarikan kebudayaan Bali dengan sasaran utama pada kalangan muda atau generasi muda saat ini.

- Positioning (Penempatan)

Film dokumenter yang mengangkat salah satu budaya yang penuh akan sejarah dan filosofi di Bali yang 
dimana masyarakat khususnya generasi muda dan masyarakat awam belum banyak mengetahui secara mendalam tentang tradisi tari rejang sutri ini.

c) Hasil Tahap 2 (Pra Produksi)

Adapaun hasil yang dilakukan pada tahapan ini antara lain:

1) Ide Cerita

Dalam film dokumenter Tari Rejang

Sutri ini akan di ceritakan tentang sejarah, tata rias, dan makna yang terkandung dalam Tari Rejang Sutri

2) Sinopsis

Sinopsis film dokumenter Tari Rejang Sutri merupakan ringkasan dari cerita yang akan ditampilkan dalam film.

3) Skenario

Skenario merupakan naskah tulis untuk sandiwara, film secara rinci dari adegan-adegan yang disusun.

4) Storyboard

Berdasarkan kronologi yang telah dibangun pada sinopsis dibuatlah storyboard sebagai langkah awal alur cerita. Storyboard yang dibangun berupa garis besar tiap prosesi yang akan ditampilkan dalam film, hal ini berarti rekaman jalannya tiap peristiwa bisa berbeda dengan yang tergambarkan dalam storyboard.

d) Hasil Evaluasi 1 (Mengecek Keterlaksanaan Tahap 1 dan Tahap 2)

Pada tahap evaluasi 1 dilakukan pengujian dengan menggunakan instrumen checklist. Hal ini bertujuan untuk mencari tahu apakah semua tahap pada model cyclic strategy telah terlaksana dengan baik.

e) Hasil Tahap 3 (Produksi dan Pasca Produksi)

Hasil tahap produksi dan pasca produksi yaitu :

a) Produksi

Tahap produksi film dokumenter Tari

Rejang Sutri telah dilaksanakan shooting dan audio recording.

b) Pasca produksi

Pada fase pasca produksi dalam pembuatan film dokumenter Tari Rejang Sutri melalui beberapa tahapan yaitu tahap video editing, audio editing, mixing, dan rendering. Software yang digunakan untuk mendukung film dokumenter yang akan dibangun adalah Adobe Premiere Pro CC 2015 dan Adobe Audition Pro CC 2015
1) Tahap Editing Video dan Audio

Tahap video editing film dokumenter Tari

Rejang Sutri mengunakan software Adobe Premiere Pro CC 2015.

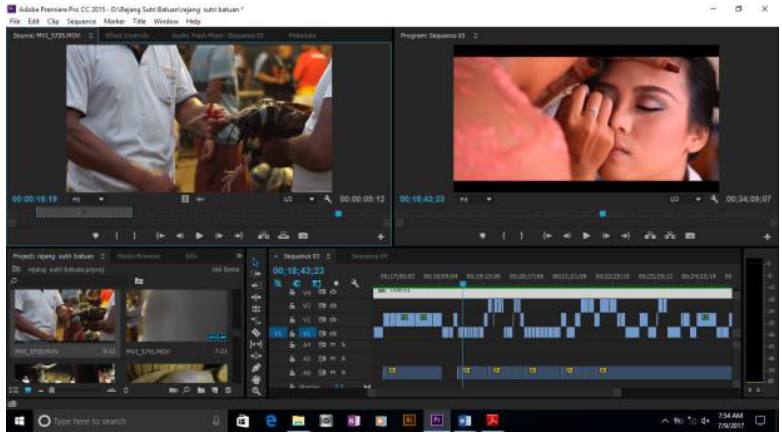

Gambar 3. Proses Editing Video

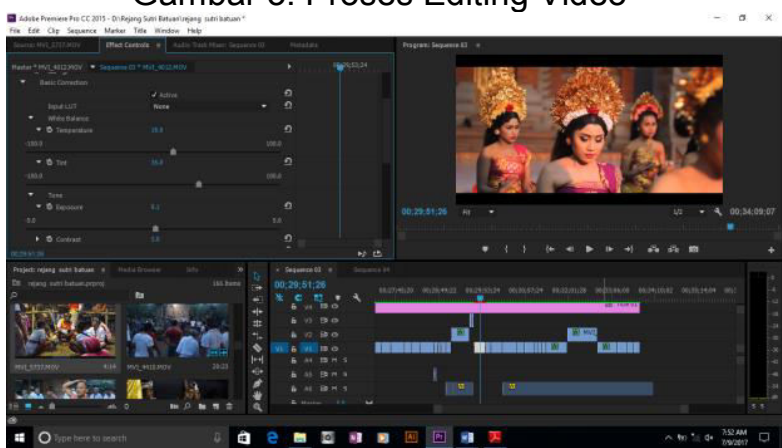

Gambar 4. Proses Color Grading

Sedangkan untuk tahap editing audio menggunakan software Audition Pro CC 2015.

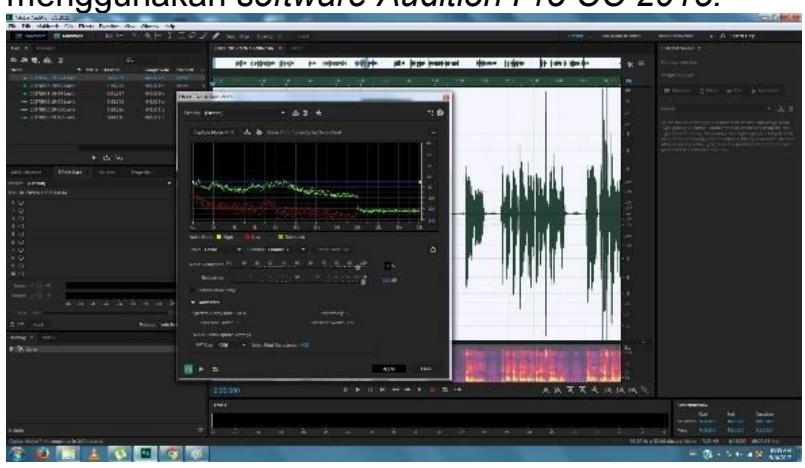

Gambar 5. Proses editing audio

2) Tahap Mixing

Tahap mixing dalam film dokumenter Tari Rejang Sutri Batuan menggunakan software Adobe Premiere Pro CC 2015. 


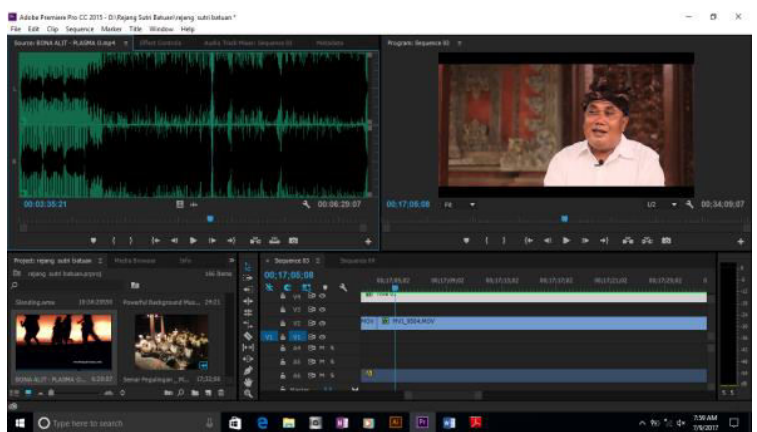

Gambar 6. Proses mixing video dan audio

\section{3) Tahap Rendering}

Proses rendering pada film dokumenter ini dilakukan setelah proses editing dan mixing telah selesai dilakukan. Proses rendering dilakukan dengan software Adobe Premiere Pro CC 2015.

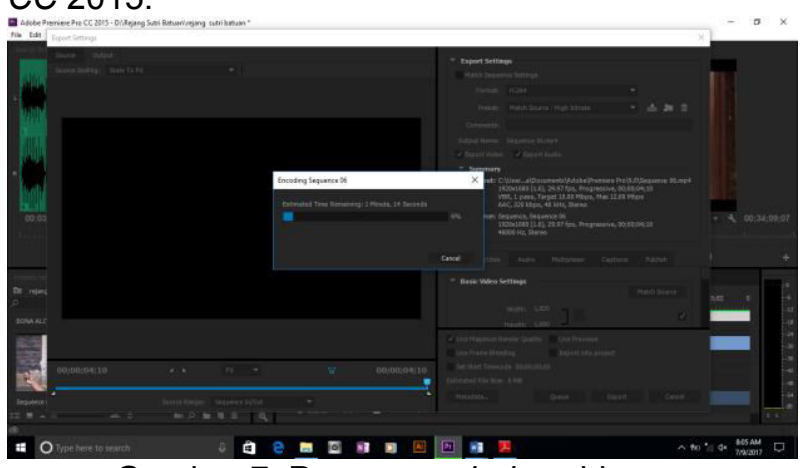

Gambar 7. Proses rendering video

f) Hasil Evaluasi 2 (Mengecek Keterlaksanaan Tahap 3)

Pada evaluasi 2 dilakukan uji validitas terhadap film documenter tari rejang sutri. Dimana hasil uji validitas memperoleh hasil sebesar $93.4 \%$ yang masuk dalam kategoti sangat baik.

g) Hasil Tahap 4 (Burning dan Desain)

Pada tahap 4 merupakan tahap akhir dari pembuatan film dokumenter. Diawali dengan proses burning. Berikut hasil pengkemasan DVD film dokumenter tari Rejang Sutri.

a) Desain Label DVD

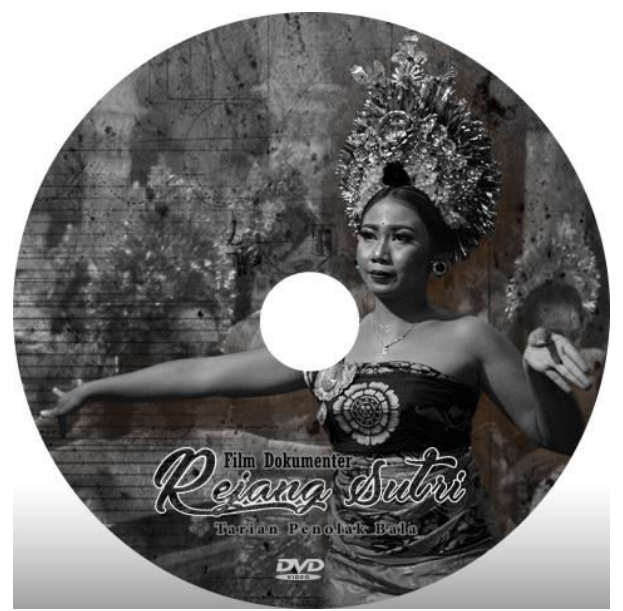

Gambar 8. Desain Label DVD

b) Desain Cover DVD

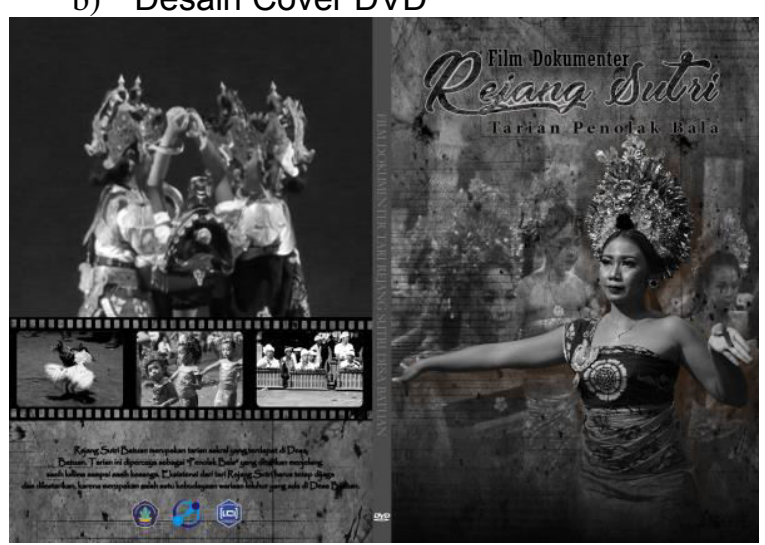

Gambar 9. Desain Cover DVD

c) Desain Poster

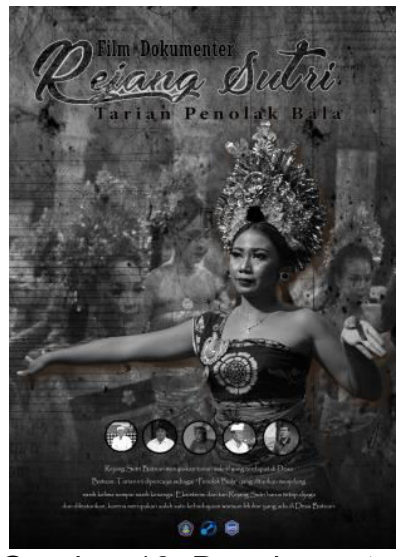

Gambar 10. Desain poster

h) Hasil Outcome

Setelah film selesai di kemas maka film akan di publikasikan sesuai dengan target yang telah ditentukan sebelumnya.

\section{B. Uji Respon}

Pada uji respon dilakukan uji efektivitas dan uji respon penonton. Uji efektivitas dilakukan untuk mengetahui tingkat pencapaian tujuan 
dari film yang dibuat. Hasil rekapitulasi uji efektivitas memperoleh persentase sebesar 93.5\% yang masuk dalam kategori sangat baik berdasarkan persentase yang telah diperoleh. Setelah itu dilakukan uji respon penonton yang dilakukan dengan 30 orang responden rentang umur 11 tahun keatas. Uji respon penonton dilakukan menggunakan instrumen angket. Hasil rekapitulasi uji respon penonton memperoleh persentase sebesar $92.37 \%$ yang masuk dalam kategori sangat baik berdasarkan persentase yang telah diperoleh.

\section{Pembahasan}

Pengembangan Film Dokumenter Tari Rejang Sutri "Tarian Penolak Bala" Tradisi Khas Desa Batuan bertujuan untuk memperkenalkan dan memberikan informasi mengenai tradisi tari rejang sutri yang ada di Desa Batuan sekaligus sebagai media yang digunakan untuk melestarikan tradisi ini. Film dokumenter tari Rejang Sutri menceritakan sejarah, fungsi, tata busana, dan nilai-nilai yang terkandung di dalam tradisi ini. Film ini juga menggunakan ilustrasi untuk membantu dalam memvisualisasikan sejarah munculnya tari rejang sutri sehingga lebih memudahkan penonton dalam menangkap informasi yang disampaikan. Film ini dibuat berdasarkan hasil wawancara dengan lima orang narasumber yang mengetahui tentang tari rejang sutri. Pengembangan film dokumenter ini menggunakan model cyclic strategy, di mana ada tujuh tahapan yang harus dilalui. Film documenter tari rejang sutri yang dikembangkan, sesuai dengan model cyclic strategy, yaitu :

1) Brief melakukan pengajuan ide ke pihak Jurusan Pendidikan Teknik Informatika dan telah disetujui. Setelah itu melakukan riset awal ke Desa Batuan.

2) Tahap 1 dilakukan pengumpulan data dan analisis terkait dengan pembuatan film documenter tari rejang sutri.

3) Tahap 2 adalah tahapan pra produksi yaitu membuat ide cerita, sinopsis, skenario, dan storyboard.

4) Evaluasi 1 dilakukan untuk menguji tahap 1 dan tahap 2 menggunakan instrumen checklist.

5) Tahap 3 meliputi tahapan produksi yaitu pengambilan gambar dan pembuatan ilustrasi dan pasca produksi yaitu editing, mixing, dan rendering.

6) Evaluasi 2 dilakukan untuk menguji film yang telah dibuat. Pada evaluasi 2 dilakukan uji validitas.

7) Tahap 4 dilakukan proses mastering dan desain. File yang telah di render akan di burn ke DVD dan dibuatkan desain agar lebih menarik.

8) Outcome adalah tahapan terakhir dalam model ini, di mana film yang telah selesai akan dipublikasikan.

Film ini dapat menambah wawasan masyarakat mengenai salah satu budaya yang ada di Desa Batuan yaitu tari rejang sutri. Karena dalam film ini terkandung nilai-nilai kearifan lokal masyarakat Bali khususnya dalam bidang seni tari tradisional Bali agar dapat tersampaikan dengan media yang lebih beragam serta inovatif dan menarik sehingga maryarakat lebih mudah untuk mendapatkan informasi.

Dalam pembuatan film dokumenter ini tidak terlepas dari segala kendala. Salah satu kendala dalam pembuatan film ini yaitu dalam cara penyampaian informasi dan pesan tentang tarian ini agar tidak terkesan monoton dan membosankan. Film dokumenter ini juga tidak luput dari kekurangan, diantaranya dalam teknik pengambilan gambar dan dalam penyajian ilustrasi sejarah tari rejang sutri.

Dibalik kekurangan tersebut, film ini juga memiliki kelebihan yaitu film ini dapat menampilkan sejarah dari tari rejang sutri Desa Batuan yang tidak banyak masyarakat ketahui. llustrasi gambar dalam animasi 2D film dokumenter ini mempermudah masyarakat untuk mengerti mengenai sejarah tarian ini. Selain itu adanya rekontruksi ulang dalam sejarah berupa tarian yang berjudul geger baturan yang ditampilkan dalam film ini dapat memberikan gambaran tentang sejarah munculnya tari rejang sutri. Dalam film ini juga diajarkan nilai-nilai yang dapat dipetik dalam menjalani kehidupan ini, serta masyarakat umum diajak untuk ikut serta melestarikan dan menjaga warisan budaya yang telah dimiliki secara turun temurun.

\section{SIMPULAN}

Berdasarkan hasil dari penelitian dan pembahasan penelitian film dokumenter tari Rejang Sutri Desa Batuan, maka penulis dapat menarik kesimpulan sebagai berikut, Film dokumenter tari rejang sutri Desa Batuan telah berhasil dilaksanakan dengan menggunakan model cyclic strategy dan menggunakan tahapan produksi film yaitu pra produksi, produksi dan pasca produksi. Karya dokumenter ini menghadirkan pemaparan melalui wawancara dengan lima orang narasumber yang mengerti tentang tari rejang sutri, di mana narasumber merupakan benang merah penjalin cerita dan visualisasi yang diwujudkan melalui pengambilan gambar dengan berbagai tipe shot 
untuk menghindari kejenuhan penonton saat menyaksikan film dokumenter tari rejang sutri. Film ini sudah diujikan dengan uji validitas yang memperoleh persentase sebesar $93.4 \%$. Selain itu film ini juga telah diuji kefektivitasannya yang memperoleh persentase sebesar 93.5\%. Berdasarkan hasil uji respon film dokumenter tari Rejang Sutri Desa Batuan terhadap 30 responden yang berasal dari generasi muda rentang umur 11 tahun ke atas di wilayah Kabupaten Gianyar, diperoleh persentase keseluruhan sebanyak 92.37\%. Hasil yang diperoleh ini dikategorikan ke dalam pencapaian sangat baik. Jadi, informasi yang terdapat pada film dokumenter tari Rejang Sutri telah tersampaikan dengan baik dan memperoleh respon pencapaian yang positif dari penonton.

\section{REFERENSI}

[1] Dibia, I. W. (2012). Ilen-llen Seni Pertunjukkan Bali. Denpasar: Bali Mangsi.

[2] Ariance, A. (2015). Penciptaan Film Dokumenter Tari Toga Dari Kerajaan Dharmasraya Kecamatan Sitiung Kabupaten Dharmasraya.

[3] Pratama, I. G., \& Soewito, B. M. (2015). Perancangan Film Dokumenter "Selonding; Nyanyianmu Semangat Kami" Sebagai Kebudayaan Khas Desa Tenganan Pegringsingan Bali. JURNAL SAINS DAN SENI ITS.

[4] Wardhani, R. K., \& Sudjudi, I. (2015).

Perancangan Video Dokumenter "AUTISME". Jurnal Tingkat Sarjana bidang Senirupa dan Desain.

[5] Pratista, H. (2008). Memahami Film. Yogyakarta: Homerian Pustaka.

[6] Ayawaila, G. R. (2008). Dokumenter Dari Ide Sampai Produksi. Jakarta: Lembaga Penerbitan Fakultas Film dan Televisi Institut Kesenian Jakarta.

[7] Semedhi, B. (2011). Sinematografi Videografi. Bogor: Ghalia Indonesia.

[8] Purba, J. (2013). Shooting Yang Benar. Yogyakarta: C.V Andi Offset.

[9] Hartono, D. (2012). Infotainmen : Proses Produksi dan Praktik Jurnalistik. Jakarta Barat: Akademia.

[10] Eko. (2013). Simulasi Digital. Jakarta: Kementrian Pendidikan dan Kebudayaan Republik Indonesia.

[11] Sarwono, J., \& Lubis, H. (2007). Metode Riset untuk Desain Komunikasi Visual. Yogyakarta: Andi.

[12] Narayana, I. P. A., Santyadiputra, G. S., ST, M. C., Pradnyana, G. A., \& Kom, S.
(2017). Film Dokumenter Tok Lait Kancing: Sebuah Warisan Karakter Budaya Bangsa. KARMAPATI (Kumpulan Artikel Mahasiswa Pendidikan Teknik Informatika) ISSN: 2252-9063, 6(1). 